\title{
Ekumenizm a realizacja misyjnego posłannictwa Kościoła w kontekście dokumentów Wszechprawosławnego Synodu na Krecie
}

\author{
bp Andrzej Borkowski \\ Katedra Teologii Prawosławnej, Uniwersytet w Białymstoku \\ Białystok, Polska \\ ORCID: 0000-0001-6431-9932 \\ borkowskiunath@yahoo.gr
}

bp A. Borkowski, Ecumenism and the implementation of the Church's missionary mission in the context of the documents of the All -Orthodox Synod in Crete, Elpis, 21 2019: 93-97.

\begin{abstract}
Resolutions of The Holy and Great Council of the Orthodox Church lay the foundations for ecumenical dialogue, emphasizing the need for dialogue primarily because of proclaiming the "Orthodox testimony" to other Christian Churches and denominations. The position of the Orthodox Church was developed regarding the principles and forms of participation in theological dialogues and in the ecumenical movement, and new resolutions were adopted confirming the all-Orthodox position. Dialogue in the Orthodox Church has always been and remains an essential and inalienable element of its soteriological mission. He has a glorious purpose for the return of those repentant to his bosom, as well as pastoral responsibility, because it unwaveringly confesses and proclaims that in its self-awareness the Orthodox Church is the authoritative continuation of the One, Holy, Catholic and Apostolic Church and the ark of salvation for those nearby and those from afar.

Streszczenie: Uchwały Wszechprawosławnego Synodu kładą podwaliny pod dialog ekumeniczny, podkreślając potrzebę dialogu przede wszystkim ze względu na głoszenie światu „prawosławnego świadectwa” wśród innych Kościołów chrześcijańskich i wyznań. Wypracowano stanowisko Kościoła prawosławnego odnośnie zasad i form uczestnictwa w dialogach teologicznych i w ruchu ekumenicznym oraz przyjęto nowe uchwały, potwierdzające wszechprawosławne stanowisko. Dialog w Kościele prawosławnym zawsze był i pozostaje istotnym i niezbywalnym elementem jego misji soteriologicznej. Przyświeca Jemu chwalebny cel powrotu skruszonych na Jego łono, jak również duszpasterskiej odpowiedzialności, gdyż niezachwianie wyznaje i głosi iż w swej samoświadomości Kościół prawosławny stanowi miarodajną kontynuacje Jednego, Świętego, Powszechnego i Apostolskiego Kościoła oraz arkę zbawienia dla tych w pobliżu i tych z oddala.
\end{abstract}

Keywords: Ecumenism, mission, Panorthodox Synod, Orthodox Church, dialogue

Słowa kluczowe: ekumenizm, misja, Synod Wszechprawosławny, Kościół prawosławny, dialog

W 1976 roku w Genewie przyjęto katalog tematyczny ustalony jeszcze podczas spotkania na wyspie Rodos w 1961 roku. Z pośród 10 tematów dwa dotyczyły „Relacji Kościoła prawosławnego z pozostałym chrześcijańskim światem” i „Prawosławia i ruchu ekumenicznego". Pomimo jednogłośnego przyjęcia powyższych tematów także podczas trzeciego spotkania w 1986 roku, na spotkaniu zwierzchników cerkiewnych w 2014 roku patriarchat moskiewski wyraził pisemnie swój sprawiedliwy pogląd, że dotychczasowe teksy potrzebują uaktualnienia. Propozycja została przyjęta jednogłośnie. W nowym wspólnym tekście przyjętym podczas piątego spotkania w 2015 roku ustalono zasadę jedno-

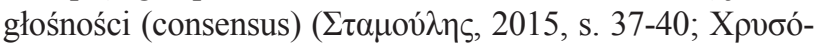

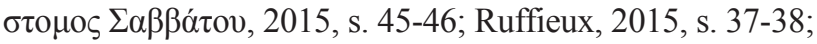
Florovskij, 2000, s. 300; Florovsky, 1972a, s. 52; Florovsky, 1972b, s. 74; Klinger, 1971, s. 309).

Nie ma wątpliwości, że jednym z ważniejszych dokumentów, a na pewno najbardziej dyskutowanym dokumentem Wszechprawosławnego Synodu, jest tekst V Przedsynodalnego Wszechprawosławnego Spotkania z października 2015 roku w Genewie zatytułowany „Relacje Kościoła prawosławnego $\mathrm{z}$ pozostałym światem chrześcijańskim". Zwrócił szczególną uwagę nie tylko prawosławnych, ale także wyznawców innych Kościołów

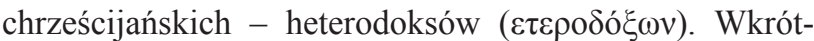
ce po opublikowaniu tekst wywołał ożywioną dyskusję,

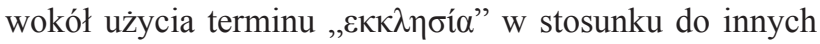
Kościołów chrześcijańskich. W rezultacie poszczególne Kościoły lokalne zaproponowały pewne poprawki w tekście. Obawiano się, aby przez charakteryzowanie wspólnot

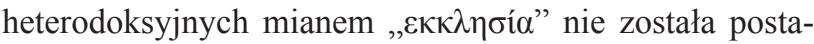
wiona pod wątpliwość jedność ontologiczna i samoświadomość Kościoła prawosławnego, będącego według eklezjologii prawosławnej „Jednym, Świętym, Powszechnym i Apostolskim Kościołem" (Grdzelidze, s. 312-313; Pańkowski, 2018, s. 3).

Dokument Wszechprawosławnego Synodu określa fundamenty i cel dialogu Kościoła prawosławnego ,z pozostałym światem chrześcijańskim”, wyznaczając pewne kierunkowe zasady, do których należy zaliczyć: 
1. Odpowiedzialność ekumeniczną Kościoła prawosławnego w dążeniu do przywrócenia jedności chrześcijan, wyrażoną w formule: „Odpowiedzialność Cerkwi prawosławnej za jedność, jak też jej powszechna misja, zostały wyrażone przez Sobory Powszechne. W sposób szczególny eksponowały one nierozerwalny związek, który istnieje między prawdziwą wiarą a wspólnotą sakramentalną" (\& 3)(Dokumenty przyjęte przez Święty $i$ Wielki Sobór Cerkwi Prawosławnej. Kreta, 18-26.06.2016 r., 2016, s. 34) ${ }^{1}$. Wspólnota sakramentalna jest zatem wyrazem i zwieńczeniem wspólnego wyznania wiary. Stanowi nierozerwalny związek „o $\rho-$

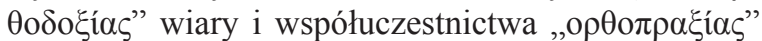
we Wspólnym Kielichu.

2. Współuczestnictwo Kościoła prawosławnego modlitwą i czynem w ruchu ku przywróceniu jedności z po-

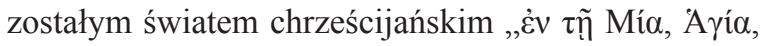

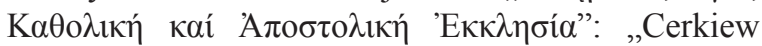
prawosława, która nieprzerwanie modli się „o zjednoczenie wszystkich", zawsze kultywowała dialog z tymi, którzy oddzielili się od Niej, bliskich i dalekich, przodowała zaś we współczesnym poszukiwaniu dróg i sposobów przywrócenia jedności wierzących w Chrystusa, brała udział w ruchu ekumenicznym od jego powstania oraz wniosła swój wkład w jego formowanie się i dalszy rozwój" (\& 4) (Dokumenty..., 2016, s. 34).

3. Samoświadomość Prawosławia. „Współczesne bilateralne dialogi teologiczne Cerkwi prawosławnej, jak również Jej udział w ruchu ekumenicznym, opierają się na samej samoświadomości Prawosławia oraz na jego powszechnym duchu, w celu poszukiwania, na podstawie prawdy wiary i tradycji starożytnej Cerkwi siedmiu Soborów Powszechnych, jedności wszystkich chrześcijan" (\& 5) (Dokumenty..., 2016, s. 35). Należy przy tym podkreślić, że ,pozostały chrześcijański świat", do którego skierowany jest dokument Wszechprawosławnego Synodu dotyczy także Kościoła rzymskokatolickiego, z którym Kościół prawosławny prowadzi od 37 lat dwustronny dialog teologiczny w duchu prawdy i miłości.

Odnośnie natury Kościoła w relacji z „pozostałym światem chrześcijańskim", ku któremu kieruje i prowadzi dialog teologiczny, dokument synodalny zaznacza przede wszystkim, że ,zgodnie z ontologiczną naturą Cerkwi, Jej jedność nie może zostać naruszona" (\& 6) (Dokumenty..., 2016, s. 35). Powyższe stwierdzenie jest tym bardziej dobitne, albowiem Kościół Chrystusowy pozostaje aż do końca świata „Jednym, Świętym, Powszechnym i Apostolski”, pomimo schizm i podziałów w jej łonie. Zakłócenia w jedności w historycznym pochodzie Kościoła nie wpłynęło na zmianę jego ontologicznej natury.

Pomimo to, zgodnie z dokumentem synodalnym Kościół prawosławny wierzy, że relacje jego z innymi hete-

\footnotetext{
Tłumaczenie na j. polski tekstów soborowych podaję zgodnie z oficjalnym thumaczeniem PAKP. Stąd różnica w terminologii. W artykule stosuję nazwę „Kościół prawosławny” natomiast w oficjalnym tekście tłumaczenia został użyty termin „Cerkiew prawosławna”.
}

rodoksyjnymi Kościołami chrześcijańskimi i wyznaniami, nie znajdującymi się w łączności z nim ,powinny opierać się na możliwie szybszym i bardziej obiektywnym sprecyzowaniu całości kwestii eklezjologicznej, szczególnie w zakresie ich ogólnego nauczania o sakramentach, łasce, kapłaństwie i sukcesji apostolskiej. W ten sposób była (tj. Cerkiew) przychylna i pozytywnie nastawiona zarówno ze względów teologicznych, jak i duszpasterskich, do dialogu z pozostałymi chrześcijanami na poziomie dwustronnym i wielostronnym oraz ogólnie do udziału w ruchu ekumenicznym czasów współczesnych" (\& 6) (Dokumenty..., 2016, s. 35). W uchwale Wszechprawoslawnego Synodu została opisana także metodologia dialogów teologicznych (\&11) (Dokumenty..., 2016, s. 36).

Uchwała Wszechprawoslawnego Synodu kładzie podwaliny pod dialog ekumeniczny, podkreśla potrzebę dialogu przede wszystkim ze względu na głoszenie światu „prawosławnego świadectwa” wśród innych Kościołów chrześcijańskich i wyznań. Zaznacza przy tym, że celem ruchu ekumenicznego jest upragniona jedność chrześcijańska. Z tym zamiarem Kościół powszechny uczestniczy w ekumenicznym dialogu miłości i prawdy za pośrednictwem głoszenia „świadectwa wiary”. Wypracowane stanowisko Kościoła prawosławnego odnośnie zasad i form uczestnictwa w dialogach teologicznych oraz w ruchu ekumenicznym jest niezwykle ważne. Przyjęto nowe uchwały, potwierdzające wszechprawosławne stanowisko, które w przeszłości bądź pomijano, bądź kwestionowano, mianowicie:

1. Usankcjonowano nie tylko sposób wyjścia pewnego Kościoła lokalnego z konkretnego dialogu ale także możliwość jego zerwania jak również zmiany metodologii lub ponownej oceny, jeśli zaistnieje taka konieczność w wyniku istotnych powodów natury eklezjologicznej, kanonicznej, pasterskiej lub etycznej. Zatem jest to procedura o wyraźnym charakterze ogólnoprawosławnej decyzji, biorącej swój początek z inicjatywy patriarchatu ekumenicznego i następnie

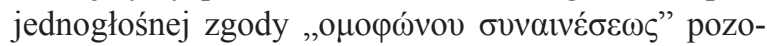
stałych lokalnych Kościołów prawosławnych (\& 10) (Dokumenty..., 2016, s. 36).

2. Określono kryteria kanoniczne (kanon 7 II i 95 Pendektu) w kontekście perspektywy dialogów teologicznych Kościoła prawosławnego z innymi Kościołami chrześcijańskimi i wyznaniami (\&20) (Dokumenty..., 2016, s. 38-39). W tym samym paragrafie określono ponadto wszechprawosławnie granice Kościoła prawosławnego wobec innych Kościołów chrześcijańskich i wyznań. Nie zakwestionowano ich istnienia ale

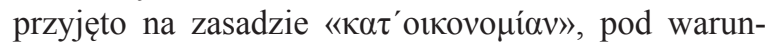
kiem hipostatyczności i ważności sakramentu chrztu

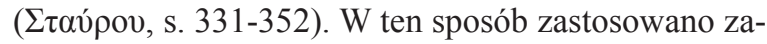
sadę ekonomii, jako wyraz filantropijnego stanowiska Kościoła prawosławnego wobec pozostałych Kościołów chrześcijańskich i wyznań, podczas gdy on sam kontynuuje także stosowanie zasady akrybii.

3. Podkreślono, że „Cerkiew prawosławna uważa za godne potępienia wszelkie rozrywanie jedności Cer- 
kwi, przez osoby lub grupy, pod pretekstem zachowania lub rzekomej obrony prawdziwego Prawosławia", gdyż uważa, że ,zachowanie prawdziwej wiary prawosławnej jest zapewniane tylko za pośrednictwem systemu soborowości, który od zawsze stanowił w Cerkwi najwyższy autorytet w kwestiach wiary" (\& 22) (Dokumenty..., 2016, s. 39). Stanowisko, które wypływa z tradycji kanonicznej (kanon 6 II Sob. Pow.) oraz nauki patrystycznej (por. Cyryl Aleksandryjski, Listy LXXII, PG 77, 3442-345B).

Z przytoczonych uchwał soborowych wynika, że relacje Kościoła prawosławnego z pozostałym światem chrześcijańskim, w sposób jaki został określony w dokumencie soborowym, wskazują na potrzebę kontynuowania dialogu, który tradycja cerkiewna ustanowiła ponadczasowo. Wobec tego należy odpowiedzieć na dwa zasadnicze pytania w kontekście prowadzonego dialogu:

1. Czy kontynuowaniu wszystkich wspomnianych w dokumencie bilateralnych dialogów teologicznych, ponad wszelkie problemy, przyświeca pierwotny cel?

2. Czy dostrzegamy pozytywne rezultaty dotychczasowego przebiegu uczestnictwa Cerkwi prawosławnej we współczesnym dialogu ekumenicznym i w bilateralnych dialogach teologicznych?

Do pozytywnej odpowiedzi na postawione pytania skłaniają nas następujące wnioski. Prowadzone dialogi ułatwiają promieniowanie świadectwa Prawosławia w pozostałym świecie chrześcijańskim oraz dają możliwość rewizji wielu tradycji Zachodu w świetle tradycji patrystycznej i doświadczenia sakramentalnego pierwszego tysiąclecia wspólnego życia Kościoła (Grdzelidze, s. 317, 319). W sposób epigramatyczny wymienię niektóre z tych rewizji. Należy do nich przyjęcie wyjaśnienia i nauki w ogólnej kwestii chrystologicznej w dialogu z Kościołami dochalcedońskimi. Adaptacja eklezjologii eucharystycznej, jako podstawy do teologicznego i eklezjologicznego zrozumienia tematów w dialogu z Rzymsko katolikami (tekst z Monachium, Nowego Balaamu i Rawenny). Zasady pierwotnej eklezjologii u Starokatolików. Uznanie przez Światową Radę Kościołów zasad przynależności do niej, uwarunkowanych wyznawaniem chrześcijańskiej doktryny triadologicznej i eklezjologicznej oraz przyjęciem Symbolu Wiary Niceo-konstantynopolitańskiego bez wstawki o filioque, będących bazą spotkań wyznaniowych.

Ze strony Kościoła prawosławnego dialog zawsze był i pozostaje istotnym i niezbywalnym elementem jego misji soteriologicznej. Przyświeca Jemu chwalebny cel powrotu skruszonych na Jego łono, jak również duszpasterskiej odpowiedzialności, gdyż niezachwianie wyznaje i głosi iż w swej samoświadomości Kościół prawosławny stanowi miarodajną kontynuacje Jednego, Świętego, Powszechnego i Apostolskiego Kościoła oraz arkę zbawienia dla tych w pobliżu i tych z oddala. Samoświadomość kościelna jest głównym kryterium każdego dialogu, określonego przez następujące granice odpowiedzialności teologicznej:

1. Wyznaczone przez prawosławne Kościoły lokalne swym członkom mieszanych komisji teologicznych lub wielostronnych dialogów teologicznych w ramach współczesnego ruchu ekumenicznego.

2. Niesłabnącej należnej troski prawosławnych Kościołów lokalnych w celu bacznego obserwowania i oceny wspomnianych dialogów, w duchu surowej krytyki, nie tylko na płaszczyźnie odpowiedzialnych organów synodalnych każdego Kościoła lokalnego, ale także przez Wszechprawosławne spotkania, albowiem temat bilateralnych i wielostronnych dialogów teologicznych został włączony do katalogu Wszechprawosławnego Soboru.

Należy podkreślić, że „O $\rho \theta 0 \delta o \xi i ́ \alpha ”$ jako własność Kościoła prawosławnego nie jest sprawą poszczególnych wyobcowanych osób, ani też nie została umieszczona poza lub ponad Nim, ale jako regulujący kanon Jego życia i myśli, utożsamiająca się z Kościołem oraz stanowiąca

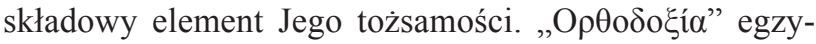
stuje wyłącznie w społeczności z Kościołem, fakt, oznaczający w danej kwestii potrzebę całkowitego przyjęcia soborowo zaakceptowanych uchwał ze strony wiernych prawosławnych, w innym przypadku grozi niebezpieczeństwo kościelnych anomalii i schizm w łonie Kościoła, wydarzeń które nanoszą śmiertelne rany Jego jedności. Za sprawą Swej samoświadomości, Kościół prawosławny utożsamia się z Jedynym, Świętym, Powszechnym i Apostolskim Kościołem, a nie w pojęciu założycielskiej lub instytucjonalnej wyłączności, czy ideologicznego wymuszania. Członkowie, uczestniczący w imieniu swych lokalnych Kościołów w dialogach teologicznych i w ruchu ekumenicznym, niezależnie czy są to duchowni czy świeccy, nie działają jako odosobnione jednostki, ale z polecenia reprezentowanych Kościołów, wyrażając w ten sposób kościelne a nie swoje indywidualne przekonania. Natomiast kościelne przekonanie jest wyrażane za sprawą wszechprawosławnych uchwał odnośnie uczestnictwa w nich oraz treści nauczania. Dlatego uczestniczący w nich są zobowiązani do informowania synodów reprezentowanych Kościołów lokalnych o przebiegu dialogów teologicznych lub ich dalszych perspektyw, składając do zatwierdzenia Synodowi Kościoła lokalnego wspólnie wypracowane dokumenty. Bez zgody synodalnej i uchwały lokalnych Kościołów prawosławnych żadna decyzja uczestników, wydana w imieniu swych Kościołów podczas dialogów teologicznych nie posiada kościelnej kanonicznej mocy prawnej.

W trakcie dyskusji nad wspomnianym tekstem podczas Wszechprawosławnego Synodu, postawiono pytanie, czy i na ile dopuszcza się w prawosławnej eklezjologii uchwalenie przez najwyższy organ synodalny, w tym przypadku Święty Wielki Synod, że „Cerkiew prawosławna przyjmuje historyczną nazwę nieznajdujących się z Nią we wspólnocie innych heterodoksyjnych Kościołów chrześcijańskich i wyznań” (\& 6) (Dokumenty..., 2016, s. 35). Pytanie w rzeczywistości polegało na tym, czy Kościół prawosławny mógłby jednocześnie pozostawać wiernym swej eklezjologii charakteryzując „Kościołami” starożytne Kościoły Wschodu, Rzymskokatolicki, Starokatolicki, czy nawet Anglikański, albowiem wszystkie inne wspólnoty 
protestanckie zostały scharakteryzowane w tekście jako „wyznania”.

We wspomnianej frazie oczywiście nie chodzi o eklezjologiczne uznanie innych, tj. heterodoksyjnych Kościołów i wyznań, ale o ich historyczne istnienie, którego nikt nie może poddać w wątpliwość. Tym nie mniej, niektórzy świeccy i duchowni teolodzy wyrazili ponownie swój pogląd, że na skutek takiego sformułowania Kościół prawosławny wydaje się skłaniać do uznania „Kościołami” heterodoksyjne wyznania, fakt oczywiście niezgodny

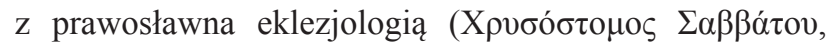
2017, s. 102).

Cały temat nabrał szczególnej powagi. Z tego względu poszczególne Cerkwie wniosły do Wszechprawosławnego Synodu, głównie ze względów duszpasterskich, o nie poruszanie $\mathrm{w}$ tekście kwestii uznawania ze strony Cerkwi prawosławnej „innych heterodoksyjnych Kościołów chrześcijańskich i wyznań", ale zwykłego uznania

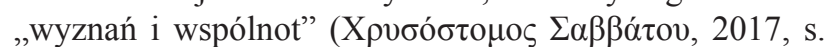
103-104). Powyższa propozycja odwróciła całkowicie nie tylko literę, ale duch Wszechprawosławnej Komisji Przygotowawczej oraz dwóch Wszechprawosławnych Spotkań Przedsynodalnych, z tego względu nie została przyjęta w tej formie przez Wszechprawosławny Synod. Ostatecznie, po burzliwych i przedłużających się dyskusjach przedłożona fraza została przyjęta $\mathrm{w}$ zmienionej formie, tj. „Cerkiew prawosławna przyjmuje historyczną nazwę nieznajdujących się z Nią we wspólnocie innych heterodoksyjnych Kościołów chrześcijańskich i wyznań” (\& 6) (Dokumenty..., 2016, s. 36). Powyższym stwierdzeniem, jak widać, środek ciężkości w spornej frazie został przesunięty z uznania historycznego istnienia heterodoksyjnych Kościołów chrześcijańskich i wyznań na zwykłe przyjęcie ich historycznej nazwy. Należy przy tym zauważyć, że z logicznego punktu widzenia jest niezrozumiałym przyjęcie historycznej nazwy heterodoksyjnych Kościołów chrześcijańskich i wyznań bez warunkowego uznania lub przyjęcia historycznego istnienia. Należy zatem sądzić, że nowa forma, którą otrzymała sporna fraza nie różni się w istotny sposób od tej w tekście V Spotkania Przedsynodalnego. Wobbec tego wspomnianą zmianę uznano za niezbędną nie tyle pod względem eklezjologicznym, ale głównie ze względów pasterskich, aby uspokoić skrajne głosy, które odzywały się w poszczególnych Kościołach lokalnych na skutek użytej frazy „,heterodoksyjnych Kościołów chrześcijańskich i wyznań".

Należy podkreślić, że podobną tendencję mogliśmy zaobserwować niemal we wszystkich przypadkach modyfikacji tekstu dokumentu podczas V Wszechprawosławnego Zebrania Przedsynodalnego. W ten sposób, $\mathrm{w}$ trzech miejscach gdzie była mowa o innych chrześcijańskich „Kościołach i wyznaniach”, powyższa fraza została wykreślona. Zamiast niej użyto następujących: „z pozostałymi chrześcijanami” (\& 6), „którzy, zgodnie z Pismem, wierzą w Jezusa Chrystusa jako Boga i Zbawiciela” (\& 19) oraz ,z pozostałym światem chrześcijańskim" (\& 20), w skutek tej zmiany powstały poważne problemy odnośnie zakresu relacji Cerkwi prawosławnej z pozostałym światem chrześcijańskim w zatwierdzonym tekście.

W tekście V Zebrania Przedsynodalnego w \& 6 czytamy, że „Cerkiew prawosławna ... była przychylna i pozytywnie nastawiona zarówno ze względów teologicznych, jak i duszpasterskich, do dialogu teologicznego z różnymi chrześcijańskimi Kościołami i wyznaniami” (ГРАМMA-

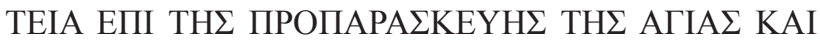
МЕГА $\Lambda$ H $\Sigma \Sigma$ YNO $\Delta O Y$ TH $\Sigma$ OP $\Theta O \Delta O \Xi O Y$ EKK $\Lambda H \Sigma I-$ $\mathrm{A} \Sigma(\dot{\varepsilon} \kappa \delta$.), 2016, s. 342). W ostatecznie przyjętym tekście nie ma mowy o dialogu teologicznym „,z różnymi chrześcijańskimi Kościołami i wyznaniami”, ale o dialogu teologicznym ,Z pozostałymi chrześcijanami na poziomie dwustronnym i wielostronnym". Tekst, zatem, sprawia wrażenie, że Kościół prawosławny prowadzi dysputy teologiczne nie z Kościołami heterodoksyjnymi i wyznania$\mathrm{mi}$, ale z chrześcijanami jako odosobnionymi osobami. Dialog teologiczny „na poziomie dwustronnym i wielostronnym" nie ma miejsca w kontekście dysputy z odosobnionymi osobami, ale między reprezentantami „Z różnymi chrześcijańskimi Kościołami i wyznaniami”, co stanowi w procedurze dialogów teologicznych niezmienną zasadę, uszanowaną przez każdy lokalny Kościół prawosławny.

W innym miejscu (\& 19), we wspominanej zmianie odnośnie tekstu dokumentu V Zebrania Przedsynodalnego teolodzy dopatrują się pewnych niejasności. Jeśli w tekście V Zebrania Przedsynodalnego jest mowa, iż „Cerkwie prawosławne - członkowie [ŚRK], uważają za warunek konieczny uczestnictwa w ŚRK artykuł - podstawę jej statutu, zgodnie z którym jej członkami mogą zostać tylko Kościoły i Wyznania, uznające Pana Jezusa Chrystusa za Boga i Zbawiciela zgodnie z Pismem i wyznające Trójjedynego Boga-Ojca, Syna i Świętego Ducha zgodnie z symbolem Nicejsko-Konstantynopolitańskim" (ГPAMMA-

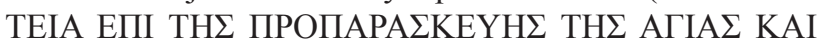
МЕГА $\Lambda H \Sigma \Sigma$ YNO $\Delta \mathrm{OY}$ TH $\Sigma$ OP $\Theta O O O \Xi O Y$ EKK $\Lambda H \Sigma I-$ $\mathrm{A} \Sigma(\dot{\varepsilon} \kappa \delta$.), 2016, s. 344-345), to w zmienionym i zatwierdzonym tekście Wszechprawosławnego Synodu spotkamy pewną niejasność, z której może wynikać, że członkami Światowej Rady Kościołów mogą być również nie tylko Kościoły i wyznania uznające Pana Jezusa Chrystusa jako Boga i Zbawiciela ale „ci, którzy, zgodnie z Pismem, wierzą w Jezusa Chrystusa jako Boga i Zbawiciela oraz wyznają zgodnie z symbolem Nicejsko-Konstantynopolitańskim Trójjedynego Boga-Ojca, Syna i Świętego Ducha" (Dokumenty..., 2016, s. 38). Innymi słowy, po przeanalizowaniu zmienionej formuły \& 19, można odnieść wrażenie, że członkowie Światowej Rady Kościołów mogą być wyodrębnionymi osobami a nie „Kościołami”.

Z porównania obydwu tekstów można wywnioskować, że zmiany uczynione $\mathrm{w}$ ostatecznie zatwierdzonym dokumencie Wszechprawosławnego Synodu nie są skierowane wyłącznie do świata chrześcijańskiego pozostającego poza Kościołem prawosławnym, odnośnie którego zamierzała określić swój zakres relacji. Pośrednio skupiono się na duszpasterskim rozwiązaniu problemów przejawiających się w skrajnych sprzeciwach mających miejsce w łonie Kościoła prawosławnego w kwestii prowadzonego dialogu 
z heterodoksami. O tym świadczy przynajmniej dodatek w \& 21, w którym heterodoksyjne wspólnoty chrześcijańskie zostały scharakteryzowane jako „nieprawosławne Kościoły i wyznania”, które „odeszły od prawdziwej wiary Jednej, Świętej, Powszechnej i Apostolskiej Cerkwi” (Dokumenty..., 2016, s. 39).

Wreszcie wydaje się istotną zmianą uczynioną w \& 17 odnośnie uczestnictwa lokalnych Kościołów prawosławnych w ŚRK. W zatwierdzonym dokumencie Wszechprawosławnego Synodu wyraźnie zaakcentowano, podobnie zresztą jak w tekście V Zebrania Przedsynodalnego, że „lokalne Cerkwie prawosławne - członkowie ŚRK - w pełni i na równi uczestniczą w strukturze ŚRK" (Dokumenty..., 2016, s. 38), fakt ukazujący na przychylne stanowisko Kościoła prawosławnego wobec ŚRK, jak również jego żywe zainteresowanie przywróceniem łączności świata chrześcijańskiego. Pomimo to, dalej czytamy, że lokalne Kościoły prawosławne uczestniczące w ŚRK ,za pomocą wszystkich środków, którymi dysponują, wnoszą swój wkład" nie jak przytoczono w tekście V Zebrania Przedsynodalnego „ku świadectwu prawdy i promowaniu jedności Chrześcijan", ale jedynie „wnoszą swój wkład w promowanie pokojowego wspótistnienia i współpracy wobec ważnych wyzwań społeczno-politycznych" (Dokumenty..., 2016, s. 38). W ten sposób w wyraźny sposób pomniejszono obecność Kościoła prawosławnego w ramach ŚRK, ograniczając jego wkład z płaszczyzny dogmatycznego i eklezjalnej, będącej głównym celem obecności w ŚRK, do roli społeczno-politycznej.

Z przyprowadzonej analizy tekstu wynika, że zmiany wprowadzone w tekście V Zebrania Przedsynodalnego podczas Wszechprawosławnego Synodu w pewien sposób osłabiły pierwotny cel jego redakcji. Początkowo dokument charakteryzował się nakierowaniem „na zewnątrz”, w celu określenia swego stanowiska wobec pozostałego świata chrześcijańskiego. Po zmianach tekst nabrał cech skierowanych „,do wewnątrz”, uczynionych w celu uspokojenia części wiernych z poszczególnych lokalnych Kościołów prawosławnych wobec wyraźnej krytyki zaangażowania Kościoła w teologiczny dialog bilateralny i wielostronny. Należy przy tym zauważyć, że Kościół prawosławny z jednej strony starał się uwrażliwić na problemy tej części wiernych, jednak z drugiej strony wyraźnie sprzeciwił się skrajnym tendencjom $w$ jej łonie, dążącym do całkowitego odcięcia się Prawosławia od dialogu teologicznego z innymi Kościołami chrześcijańskimi i wyznaniami. Potępił wszelkie tendencje do zamykania się samych w sobie, bez potrzeby interesowania się przywróceniem jedności w świecie chrześcijańskim.

\section{Bibliografia}

Dokumenty przyjęte przez Święty i Wielki Sobór Cerkwi Prawostawnej. Kreta, 18-26.06.2016 r. (2016), „Cerkiewny Wiestnik" 4 (2016).

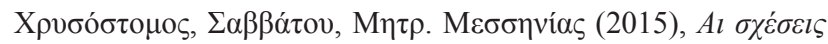

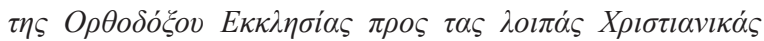

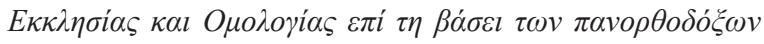

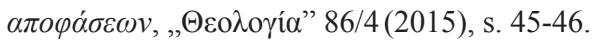

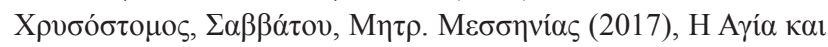

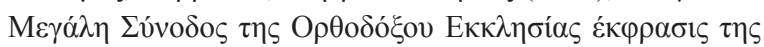

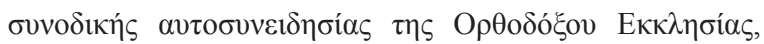
A $\theta$ ńva.

Florovskij, G. (2000), Avtoritet drevnih Soborov i predanie otcov, [w:] idem, Izbrannye bogoslovskie stat'i, Probel, Moskva [Флоровский, Г. (2000), Авторитет древних Соборов и предание отиов, [w:] idem, Избранные богословские статьи, Пробел, Москва].

Florovsky, G. (1972a), The Catholicity of the Church, [w:] idem, Collected Works, vol. 1: Bible, Church, Tradition: An Eastern Orthodox View, Nordland Publishing Company, Belmont.

Florovsky, G. (1972b), The Function of Tradition in the Ancient Church, [w:] idem, Collected Works, vol. 1: Bible, Church, Tradition: An Eastern Orthodox View, Nordland Publishing Company, Belmont 1972.

ГРАММАТЕIA ЕПI ТН $\Sigma$ ПРОПАРА ККЕYН $\Sigma$ ТН $\Sigma$ АГІА $\Sigma$ KAI MEГA $\Lambda$ $\Sigma$ $\Sigma$ YNO $\Delta O Y$ TH $\Sigma$ OP $\Theta O \triangle O \Xi O Y$ EK-

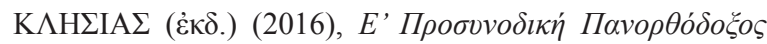

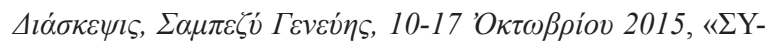

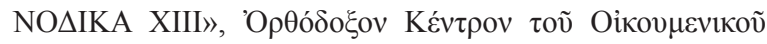

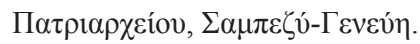

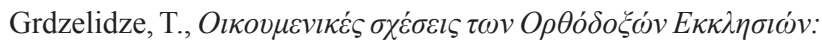

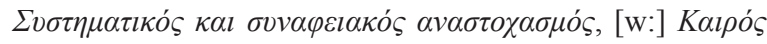

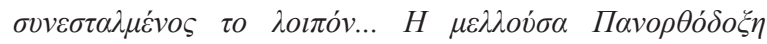

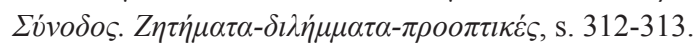

Klinger, J. (1971), Tradycja starochrześcijańska w doktrynie i duchowości Kościolów Wschodnich, „Studia Theologica Varsaviensia" 9/1 (1971).

Pańkowski, J., abp (2018), Kościót prawostawny a ekumenizm, „Polski Żołnierz Prawosławny” rok XXIII, nr 1/94 (2018).

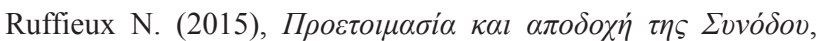

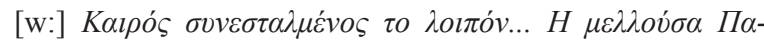

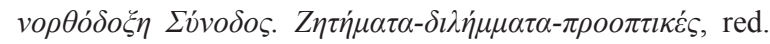

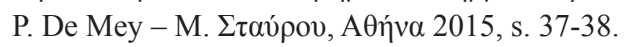

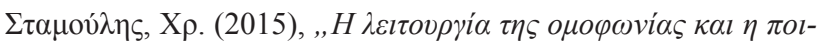

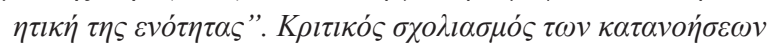

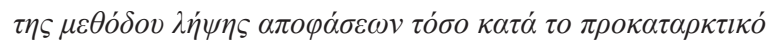

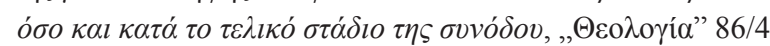
(2015), s. 37-40.

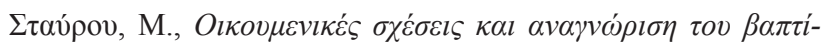

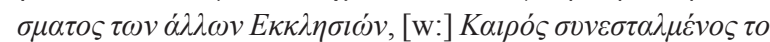

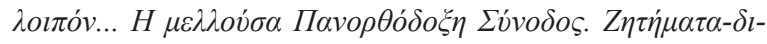

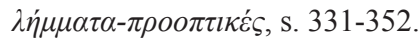


ISSN 1508-7719

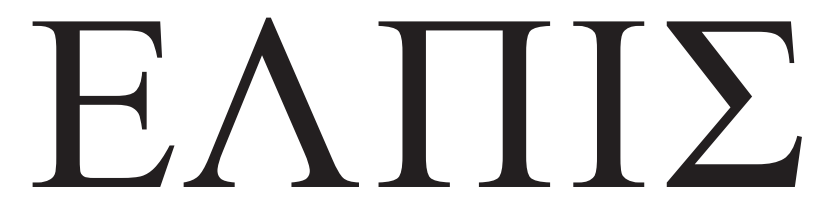

CZASOPISMO TEOLOGICZNE KATEDRY TEOLOGII PRAWOSŁAWNEJ UNIWERSYTETU W BIAŁYMSTOKU

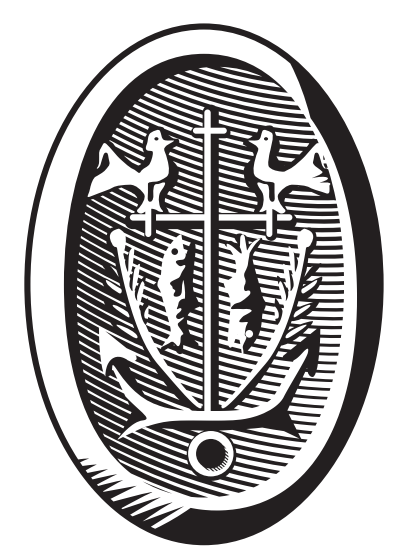

ADRES REDAKCJI

ul. Ludwika Zamenhofa 15, 15-435 Białystok, Polska tel. 85 745-77-80, e-mail: elpis@uwb.edu.pl www.elpis.uwb.edu.pl 